v. $11, n .4$

Vitória-ES, Jul.-Ago. 2014

p. 28 - 52 ISSN 1808-2386 DOI: http://dx.doi.org/10.15728/bbr.2014.11.4.2

\title{
An Analysis of the Effects of Promotion and Shelf Position on Store Revenue
}

\author{
Valter Afonso Vieria ${ }^{\dagger}$ \\ Universidade Estadual de Maringá - UEM \\ Luis Fernando Camilo ${ }^{\Omega}$ \\ Universidade Estadual de Maringá - UEM
}

\begin{abstract}
This article examines the influence of shelf placement and the ways of presenting prices at supermarkets. We carried out an experimental longitudinal study for three months in a supermarket involving nine common products, divided by placement into three shelf positions (upper area, middle area and lower area) and three price presentation strategies. These were the supermarket's standard price sticker for the base month (control) and two new presentations: the first a poster with the appeal "Compare", and the second the same type of poster with the appeal "Compare" plus " $30 \%$ Discount". We then analyzed the variations in sales of the products and the impact on the store's revenues from the display areas. The results showed that: $(i)$ higher stimuli (posters) boosted sales; $(i i)$ the poster with the appeal "Compare" was the best form of price presentation; (iii) of the nine products studied, only four had a significant impact on the revenue in more than one month; and (iv) the middle (prime) shelf area attracted the most sales, followed by the lower area.
\end{abstract}

Keywords: Price presentation. Marketing. Promotion. Supermarkets.

Received on March 10, 2013; reviewed on June 4, 2013; accepted on June 27, 2013; disclosed on August 29, 2014.

*Author for correspondence:

$\uparrow$. Postdoctorate in Business Administration from EBAPE-FGV

Institution: Professor at Maringá State University. Address: Av. Colombo 5790, Maringá - PR - Brazil

E-mail: valterafonsovieira@gmail.com

\footnotetext{
$\Omega$ Bachelor's in Administration from Maringá State University Institution: Maringá State University

Address: Rua Castro Alves, Maringá - PR - Brazil

E-mail: 1fernando3@hotmail.com

Telephone: (44) 8819-5305
} 


\section{INTRODUCTION}

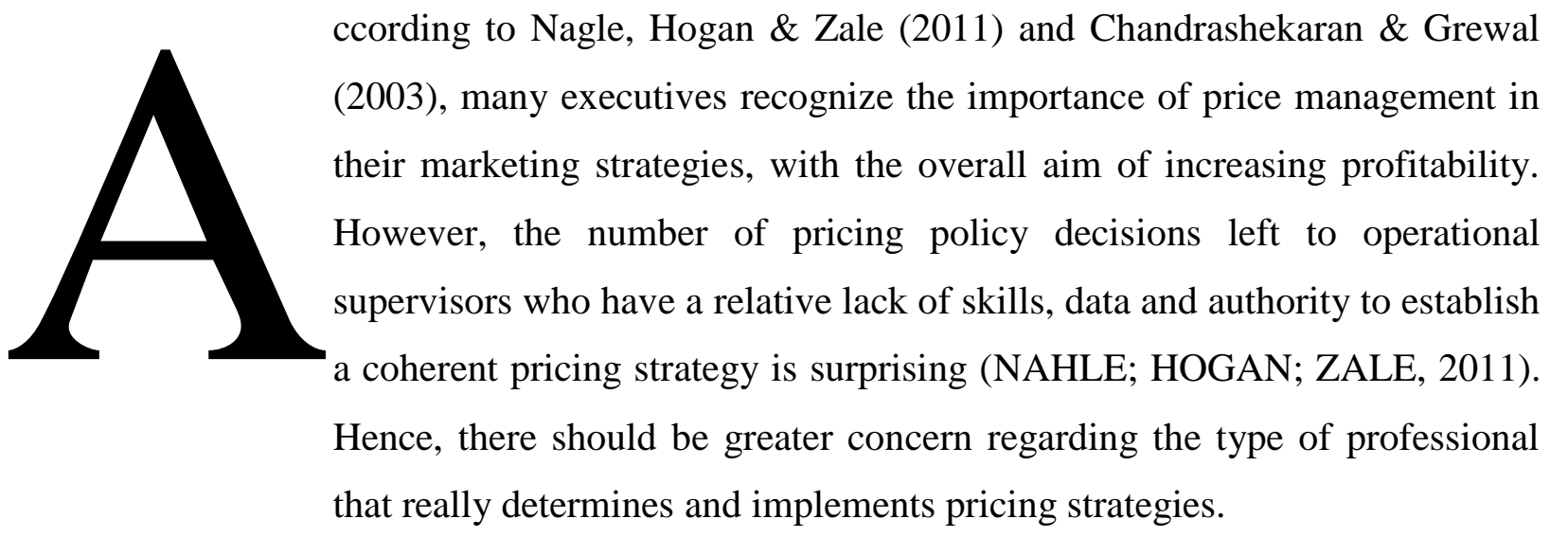

One study showed that organizations that have value-driven pricing strategies instead of strategies based on cost, revenue or mark-up can earn operating profits on average $24 \%$ higher than their competitors (HOGAN, 2008). Hence, it appears that pricing strategy can have a substantial impact on business performance.

Companies can manipulate/manage the presentation of prices in various ways aiming to boost sales (HASSELDINE; HITE, 2006). For example, some of the presentation mechanisms primarily involve the strategy of manipulating/managing the number " 99 " at the end of the price (e.g., a discount from $\mathrm{R} \$ 7.00$ to $\mathrm{R} \$ 5.99$ ). The idea is that customers tend to perceive the first number on the left as the most relevant, thus getting the idea that the discount is $\mathrm{R} \$$ 2.00 when it really is $\mathrm{R} \$ 1.01$, or in percentage terms that the price reduction is $28.5 \%$ (2.00/7.00) instead of the real figure of $14.42 \%$ (1.01/7.00). The same idea is also commonly used with whole number values for bigger ticket items. For instance, instead of marking down the price from $R \$ 500.00$ to $R \$ 400.00$, the store can reduce it to $R \$ 399.00$. In either case the difference is about $\mathrm{R} \$ 100.00$. The impact of the presentation of monetary values to consumers can increase sales substantially and be perceived as savings ranging from $20 \%$ to 75\% (SCHINDLER; KIBARIAN, 1996). There are various other ways of price presentation that, due to space limitations, are not discussed here (SCHINDLER; KIBARIAN, 1996, GUEGUEM; JACOB, 2005).

Retailers also have the option of manipulating/altering the presentation of installment payments to customers, for example $\mathrm{R} \$ 600.00$ in $12 \times$ without interest, $\mathrm{R} \$ 600.00$ divided into 12 installments without interest, or $12 \times \mathrm{R} \$ 55.00$. Note that the result is the same (BAGCHI; DAVIS, 2002). The objective in this case is to urge price-sensitive customers to buy items through installment payments that they might not purchase in a lump sum, with the 
added benefits of generating a stronger stream of future receivables and establishing a longerlasting relationship with the customer.

The investigation of the effects of price presentation on consumers' buying behavior (SRIVASTAVA; CHAKRAVARTI, 2011), without manipulating/altering the absolute price, is known in the literature as the study of comparative pricing (MONROE, 1990). Comparative pricing seeks to compare the promotional price with some relevant information to persuade the consumer to buy, such as the price of a similar item from a competitor or another interesting piece of information.

Studies of comparative price advertising are complex and have reached diverging results. Some authors have concluded that comparative advertising generates advantages for merchants (DROGE; DARMON, 1987; PEACHMANN; RATNESHWAR, 1991; PECHMANN; STWART, 1990) while others report there can be undesirable effects, such as causing doubts among customers (BELCH, 1981; GOLDEN, 1979; GOODWIN; ETGAR, 1980). Also, factors besides price also affect consumers' buying decisions. Therefore, advertising comparisons often consider factors beyond those described here, such as involvement, store ambience, type of product, type of respondents, among others. The conflicting findings can generate doubts for retailers about the effectiveness of comparative advertising and its interplay with other store aspects. Therefore, comparative advertising should be analyzed on a case-by-case basis for each product, with only a few types of comparisons. The objective of this article is to verify the influence of the forms of presenting prices and shelf position on store revenue. The specific questions analyzed are:

- What is the influence of provocative stimuli (in terms of arguments) on sales?

- What is the influence of shelf positioning on sales?

- What is the influence of the interaction of provocative stimuli and shelf positioning on sales?

To meet these objectives, we carried out an experimental study between June and August 2011 at a midsized supermarket. We chose nine products divided into three shelf positions (upper, middle, or prime, and lower), with the price and position kept uniform during the three months, only varying the price presentation. These were the standard sticker of the base month ("control") and two new forms of presenting the price in the following months: the first a poster with the appeal "Compare" and the second with a similar poster, but with the appeal "Compare: 30\% Discount". We then analyzed the performance of the 
forms of price presentation, the relative impact of the products on the store's revenue and the performance of each shelf position. We began with four assumptions: $(i)$ stronger stimuli (posters) boost sales; (ii) the more appeals offered, the higher sales will be; (iii) all the products studied have a significant impact on the store's revenue; and (iv) the prime shelf area is more propitious for sales. Only two of these assumptions were confirmed.

\section{THEORETICAL REVIEW}

\subsection{PROMOTION OF SALES}

According to Peattie \& Pettie (1995) and Liao (2006), sales promotion includes all marketing communication activities, ranging from those associated with advertising to inperson selling and public relations, with the objective of encouraging the purchase of a product. There are two types of sales promotion generally considered in the comparative pricing literature.

First, monetary sales promotion includes better financing terms, price discounts, coupons, bonuses and others (GUPTA, 1988; VILLAREJO-RAMOS; SANCHEZ-FRANCO, 2005; PAPATLA; KRISHNAMURTHI, 1996). Monetary sales promotion has an empirically proven relationship with several variables, such as increased sales in the short term (BAWA; SHOEMAKER, 1987), overall purchase volume (JONES; LYNCH, 2007), brand visibility (GARRETSON; CLOW, 1999) and induction of user experience (LEE, 2002). Chandon et al. (2000) investigated the effectiveness of sales promotion in relation to its congruence with the product being promoted. The results indicated that a promotion or sale is evaluated by the level of dominant benefits it provides. Monetary promotions are more effective for utilitarian products and non-monetary ones are better for hedonic products.

Second, non-monetary sales promotions include distribution of free samples, prize drawings, free gifts, contests and reward programs, among others (ALVAREZ; CASIELLES, 2005; PRADO; PRADO 2005; LEE, 2002). Non-monetary sales promotion can have a significant impact on the variables willingness to try new products (LEE, 2002; LAROCHE et al., 2003), buying intention (GUPTA, 1988) and market share (CHANDON et al., 2000). Mela et al. (1997) examined the long-run effects of monetary and non-monetary promotion and advertising on buyers' choices. The results showed that advertising generates greater price sensitivity, encouraging shoppers to look for special sales offers. Wakefield \& Bush (1998) investigated the responses to promotions of leisure services. The results showed that the most emotional characteristics of customers influenced the responses to monetary and non-monetary promotions. 


\subsection{COMPARATIVE PRICING}

Grewal et al. (1997) showed that when a brand is a market leader (i.e., well known), noncomparative advertisements are perceive as being more informative than are comparative ads. Further according to them, the use of two or more brands in comparative ads attracts the self-relevant selective attention of more people than do advertisements featuring only one brand.

Chandrashekaran, Compeau \& Grewal (2002) stated that when consumers are exposed to an advertisement with a credible reference price, they tend to use it and focus on the price to assess the cost-benefit relation of the transaction. Based on this, the conclusion is that the lower the sale price, the better consumers' perception will be in the value of the transaction, as long as the comparison is not perceived as being deceptive. But some theories suggest a negative effect of long-term promotion on the attitudes and behavior of consumers. According to Dodson, Tybout \& Stemthal (1978), theories of self-perception imply that consumers who buy a product when it is on sale attribute this behavior to the presence of the deal rather than their preferences for the brand.

Ehrenberg, Hammond \& Goodhitrdt (1994), using data from four weeks before and four weeks after large promotions, concluded that promotions for established brands do not have a notable effect on subsequent purchasing or brand loyalty. Davis, Inman \& McAlister (1992) performed a controlled experiment during three months and concluded that promotions do not have a negative effect on brand assessment.

Chandrashekaran, Compeau \& Grewal (2002) performed a study involving the believability of advertisements with reference prices. According to the authors, even when consumers do not entirely believe the claimed reference price, it still influences their perception of value. In other words, when the reference price increases and the sale price remains the same, consumers perception of the transaction value increases even when they do not fully trust the reference price, but when the sale price decreases and an exaggerated reference price is maintained, their perceived transaction value does not increase.

Economists have developed two theories with opposite effects of advertising regarding consumers' price sensitivity. For Comanor \& Wilson (1974), the first suggests that advertisements that differentiate prices reduce consumers' price sensitivity. The second, according to Nelson (1974), suggests that advertisements increase competition by supplying information to consumers and make them more sensitive to prices. Mitra \& Lyncb (1995) conciliated these two conflicting theories, suggesting that advertising affects the price 
elasticity of buying behavior: it can increase price elasticity by increasing the number of brands considered, but it can also diminish price elasticity by enhancing the relative strength of the preferred brand.

Companies have been increasing their trade promotion efforts. From 1990 to 1995, this increase was nearly 70\%. According to Mela, Gupta \& Lehmann (1997), Forbes magazine (1991) also reported in increase in spending on trade promotion of goods sold together from $50 \%$ to $75 \%$ of the marketing budget between 1985 and 1990. This induced a loss of $8 \%$ to $15 \%$ of the market share of the top three brands in various categories, such as popcorn, dishwashing detergent, cat food, barbecue sauce and frozen dinners. The authors also mentioned that Business Week (1991) reported that the shift in spending from advertisements to promotions was due to the declining number of consumers who only buy well-known brands, from $77 \%$ in 1975 to $62 \%$ in 1990.

\subsection{STIMULI}

Stimuli play a fundamental role to attract consumers' attention. They should be under the control of a marketing professional for definition and allocation so as to best contribute to the organization's objectives. This powerful tool can attract the attention of consumers regardless of the individual or the situation (HAWKINS; MOTHERBAUGH; BEST, 2010).

Materials at the point of sale are examples of these stimuli, widely used by retailers, and these actions can have a substantial impact on sales. A recent survey conducted by the Brazilian branch of POPAI (Point of Purchase Advertising International - an international association specialized in in-store merchandising) found that nearly 200 thousand consumers per week passed through the stores chosen in the study, and each one remained inside for an average of 27 minutes. The findings also indicated that:

- $68 \%$ of shoppers of super and hypermarkets are women and $32 \%$ are men;

- $22 \%$ are young adults (18 to 29 years old);

- while women, most of them married, still predominate in stores, male presence has been growing;

- $72 \%$ of consumers prefer to shop near their homes;

- $71 \%$ of consumers have an idea of what they intend to buy, but only $11 \%$ take a list; 
- $38 \%$ of consumers browse through all the aisles, while the rest go directly to the aisles where the items they want to buy are located; and

- $25 \%$ of the items purchased were not originally planned, but the amount spent is roughly the same as initially intended.

Hawkins, Mothersbaugh \& Best (2010) also described the factors related to stimuli, mentioning size, intensity, visual attractiveness, color and movement, position, isolation, contrast, expectations and amount of information.

\section{METHODOLOGY}

To perform the study, we chose nine products, the prices of which were maintained constant during the three-month study period. To assure the veracity of the results, we made three visits to the supermarket per week during three months in 2011 ( 3 visits $x 4$ weeks x 3 months $=36$ visits), to avoid low or no stock and deterioration of the store posters. The sales database contained the following information (variables), with no modification in the standard form of price presentation in relation to 2010. The variables were: total sales of each product in 2010 (June, July and August) and 2011 (June, July and August); average daily sales of the product in 2010 (June, July and August) and 2011 (June, July and August); gross sales revenue in 2010 (June, July and August) and 2011 (June, July and August); total sales of items in the upper shelf position in 2010 (June, July and August) and 2011 (June, July and August); total sales of items in the middle shelf position in 2010 (June, July and August) and 2011 (June, July and August); and total sales of items in the lower shelf position in 2010 (June, July and August) and 2011 (June, July and August).

The only change carried out in the period from June 1 to August 31, 2011 was the form of price presentation. As shown in Figure 1, in the first month (June 2011), the price presentation was the standard form used in the supermarket, a yellow label placed at the edge of the shelf under the product space, measuring $3 \mathrm{~cm}$ in height by $8 \mathrm{~cm}$ in length $\left(24 \mathrm{~cm}^{2}\right)$, containing an abbreviated product description and the price. In the second month (July 2011), the price was presented by means of a poster with yellow, blue and red writing on a white background, measuring $14 \mathrm{~cm}$ in height by $20 \mathrm{~cm}$ in length $\left(280 \mathrm{~cm}^{2}\right)$, with the word "Compare" followed by a description of the product and the store's logo. Finally, in the third month (August 2011), a new poster was used, similar to the other but with the addition of the expression "30\% Discount". 


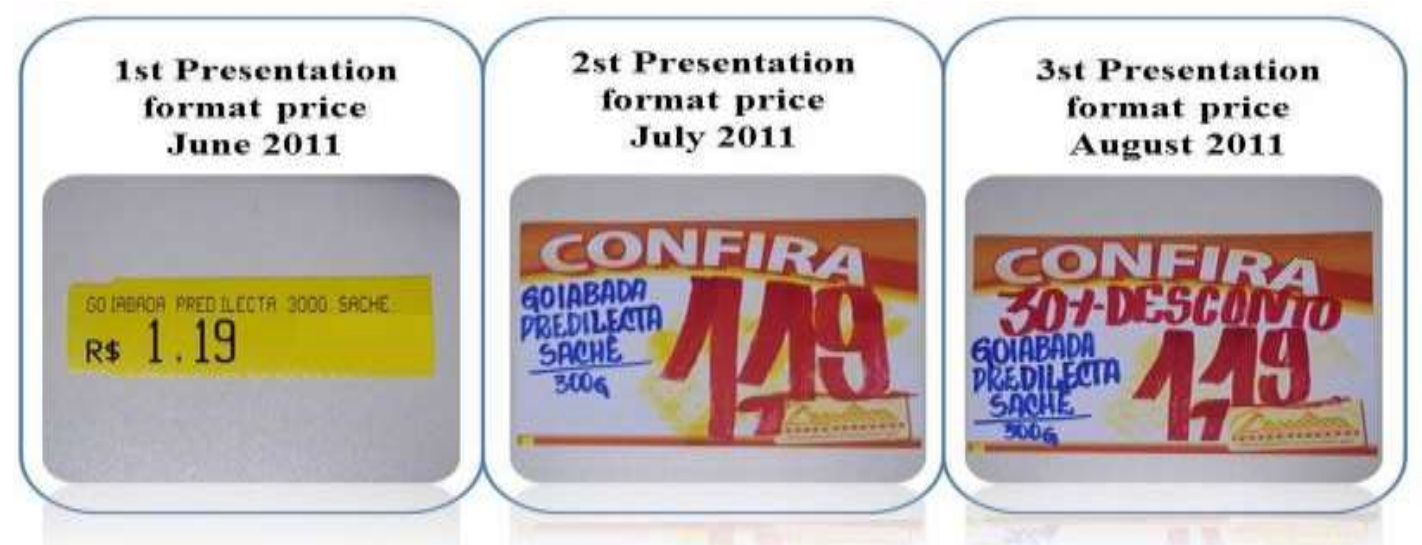

Figure 1 - Examples of the three forms of price presentation (June, July and August, respectively)

Table 1 presents the prices of the products, the width, height and area of the display and the percentage of the shelf space used. The canola oil used the greatest percentage.

Table 1 - Price and Display Area of the Products on the Supermarket Shelf

\begin{tabular}{|c|c|c|c|c|c|}
\hline Product & Price & Width & Height & $\begin{array}{l}\text { Total } \\
\text { Exposure }\end{array}$ & $\%$ of Shelf Used \\
\hline Paraná matches & $\mathrm{R} \$ 1.59$ & $34 \mathrm{~cm}$ & $13 \mathrm{~cm}$ & $442 \mathrm{~cm}^{2}$ & $1.9 \%$ \\
\hline Super Clean aluminum polish & $\mathrm{R} \$ 1.49$ & $17 \mathrm{~cm}$ & $26 \mathrm{~cm}$ & $442 \mathrm{~cm}^{2}$ & $1.9 \%$ \\
\hline Suavit canola oil & $\mathrm{R} \$ 5.29$ & $40 \mathrm{~cm}$ & $56 \mathrm{~cm}$ & $2,240 \mathrm{~cm}^{2}$ & $9.8 \%$ \\
\hline Olé corn & $\mathrm{R} \$ 1.35$ & $30 \mathrm{~cm}$ & $10 \mathrm{~cm}$ & $300 \mathrm{~cm}^{2}$ & $1.3 \%$ \\
\hline Monsil cassava flour & $\mathrm{R} \$ 2.19$ & $23 \mathrm{~cm}$ & $26 \mathrm{~cm}$ & $598 \mathrm{~cm}^{2}$ & $2.6 \%$ \\
\hline Apti cornstarch & $\mathrm{R} \$ 1.99$ & $48 \mathrm{~cm}$ & $24 \mathrm{~cm}$ & $1,152 \mathrm{~cm}^{2}$ & $5.0 \%$ \\
\hline Predilecta guava paste & $\mathrm{R} \$ 1.19$ & $23 \mathrm{~cm}$ & $19 \mathrm{~cm}$ & $437 \mathrm{~cm}^{2}$ & $1.9 \%$ \\
\hline 5 Cinco acetone spot remover & $\mathrm{R} \$ 3.19$ & $17 \mathrm{~cm}$ & $13 \mathrm{~cm}$ & $221 \mathrm{~cm}^{2}$ & $1.0 \%$ \\
\hline Removex household cleaner & $\mathrm{R} \$ 4.99$ & $58 \mathrm{~cm}$ & $30 \mathrm{~cm}$ & $1,740 \mathrm{~cm}^{2}$ & $7.6 \%$ \\
\hline Average & $R \$ 2.59$ & 34.14 & 25.43 & $955.43 \mathrm{~cm}^{2}$ & $4 \%$ \\
\hline
\end{tabular}

Source: Data gathered under coordination of the authors (June-August 2011).

In terms of position on the shelf, the products were distributed into three groups (lower, middle and upper), where they remained during the three months. None of the products were also displayed in other places in the store during the experimental period.

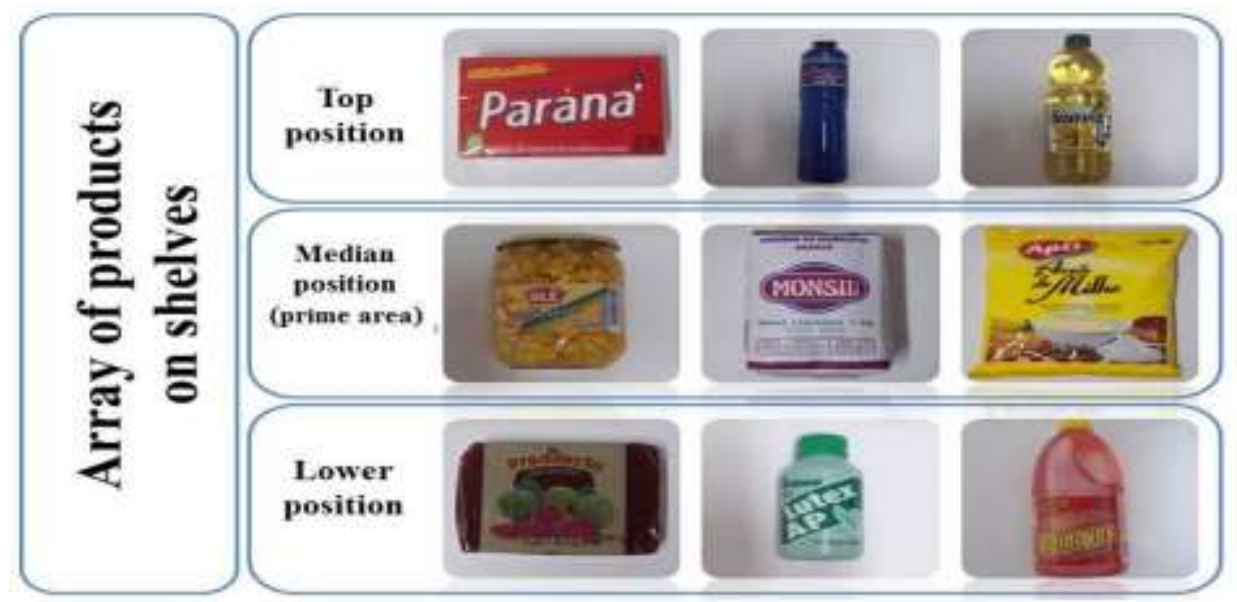

Figure 2 - Shelf position of the products 
Sample. The universe corresponded to all the people who entered the supermarket in the period from June 1 to August 31, 2010 and the same period in 2011. During these periods, approximately 30 thousand customers entered the store. The period in 2010, without manipulation of the forms of price presentation, served as the parameter for comparison to the same period in 2011, during which the marketing strategies were manipulated. The sample was thus non-probabilistic and by convenience.

Data collection and treatment. The data on sales of the products in 2010 and 2011 were recorded using the FLEX DB® software, a specialized program for supermarkets produced by the company RP Informática. The paired $t$-test was used to compare the means of the selling strategies.

\section{RESULTS}

\subsection{PARANÁ MATCHES}

Paraná matches did not present relevant results in terms of variation in the averages of the three price presentation strategies used. The statistical tests used did not show any significant variation in the means. The average of the control strategy (2.09) was lower than that of the compare appeal (3.61) and also lower than that of the compare plus $30 \%$ discount appeal (2.70), but the difference was not significant in either case: $M_{\text {control }}=2.09$ vs. $M_{\text {compare }}=$ $3.61(t=1.50 ; p<0.14) ; M_{\text {control }}=2.45$ vs. $M_{\text {compare: }} 30 \%$ discount $=2.70(t=0.28 ; p=\mathrm{NS})$; and $M_{\text {compare }}=3.76$ vs. $M_{\text {compare: }} 30 \%$ discount $=2.42(t=0.28 ; p<0.14)$, where " $M$ " indicates the daily mean number of units sold.

The average sales increased from the control to the compare appeal and fell with the addition of the $30 \%$ discount appeal, but both were higher than the standard price label (control), suggesting a positive alteration. From June to July (standard price label to compare), sales rose on average from $M_{\text {control }}=2.09$ to $M_{\text {compare }}=3.61$ (growth of about $70 \%$ ). With the addition of the discount appeal, the average sales decreased from $M_{\text {compare }}=3.76$ to $M_{\text {compare: }} 30 \%$ discount $=2.42$, a decline of approximately $45 \%$ in relation to the previous month. Thus, the compare strategy performed the best.

According to Figure 3, 54 units of Paraná kitchen matches were sold with the standard price label, 85 with the compare poster and 66 with the compare: 30\% discount poster, an increase of $57 \%$ from the first to the second and of $22 \%$ from the first to the third.

There was a small variation in average daily sales from one year to the other — from $M_{2010}=2.12$ in 2010 to $M_{2011}=2.16$ in 2011 . Hence, there was a tendency for similarity 
between the two years with the standard price label. Given that evidence, there is a possibility of future increases produced by new price presentation forms.

Analysis of the match sector of the market rather than the specific brand showed average sales figures of $M_{\mathrm{June}}=16.12, M_{\mathrm{July}}=21.00$ and $M_{\text {August }}=16.04$. So, there was a $30 \%$ increase from June to July and a drop of $24 \%$ from July to August. In general, the specific product accompanied the movements of the sector, except the average for August was not lower than that for June, perhaps due to the presence of the additional discount appeal.

The main competitor of the product (Paraná matches), Fiat Lux matches w/240, presented the following means in 2011: $M=2.36$ in June, $M=3.27$ in July and $M=1.81$ in August. Therefore, both the competing brand and the product studied accompanied the fluctuations of the sector. However, the compare plus discount poster might have prevented a larger decline in sales of Paraná matches. To summarize, neither of the strategies was particularly effective. The compare appeal did not bring significant improvements and the addition of the discount appeal at most prevented a larger fall in sales.

Table 2 - Mean Sales per Month of Each Product and of the Corresponding Overall Sector

\begin{tabular}{|c|c|c|c|c|c|c|}
\hline \multirow[b]{2}{*}{ Products } & \multicolumn{3}{|c|}{ Mean of the Product } & \multicolumn{3}{|c|}{ Mean of the Overall Sector } \\
\hline & Control & Compare & $\begin{array}{l}\text { Compare: } \\
\text { 30\% } \\
\text { discount }\end{array}$ & June & July & August \\
\hline Paraná matches ${ }^{\mathrm{a}}$ & $2.16^{\mathrm{NS}}$ & $3.26^{\mathrm{NS}}$ & $2.53^{\mathrm{NS}}$ & 16.12 & 21.00 & 16.04 \\
\hline Super Clean aluminum polish ${ }^{\mathrm{a}}$ & 1.80 & $3.03 \dagger$ & $3.65 t$ & & & \\
\hline Suavit canola oil ${ }^{\mathrm{a}}$ & $1.56^{\mathrm{NS}}$ & $1.61^{\mathrm{NS}}$ & $1.80^{\mathrm{NS}}$ & 2.32 & 2.81 & 2.85 \\
\hline Olé corn ${ }^{\mathrm{b}}$ & 2.00 & 3.34 & 3.23 & 36.96 & 45.00 & 38.00 \\
\hline Monsil cassava flour ${ }^{b}$ & $2.00^{\mathrm{NS}}$ & $2.46^{\mathrm{NS}}$ & $2.65^{\mathrm{NS}}$ & 9.00 & 11.62 & 10.23 \\
\hline Apti cornstarch ${ }^{\mathrm{b}}$ & 2.24 & 4.19 & 3.65 & 8.00 & 9.69 & 8.38 \\
\hline Predilecta guava paste $^{c}$ & 3.08 & 7.34 & 5.80 & & & \\
\hline 5 Cinco acetone spot remover ${ }^{c}$ & 0.84 & 1.50 & 2.30 & 4.84 & 6.34 & 7.00 \\
\hline Removex household cleaner $^{c}$ & 0.72 & 1.42 & 1.26 & 2.44 & 2.61 & 3.07 \\
\hline
\end{tabular}

Source: Data gathered under coordination of the authors (June-August 2011); the first three columns show the average daily sales in the month of the specific product, while the last three columns show the average sales of the sectors (matches, oil, guava paste, etc.). ${ }^{\mathrm{a}}$ upper position, ${ }^{\mathrm{c}}$ lower position and ${ }^{\mathrm{b}}$ middle position on the shelf; $\mathrm{NS}=$ not significant; $\dagger$ difference between control and compare $\mathrm{p}<0.05$ and $\ddagger$ difference between control and compare: $30 \%$ discount $\mathrm{p}<0.05$. 


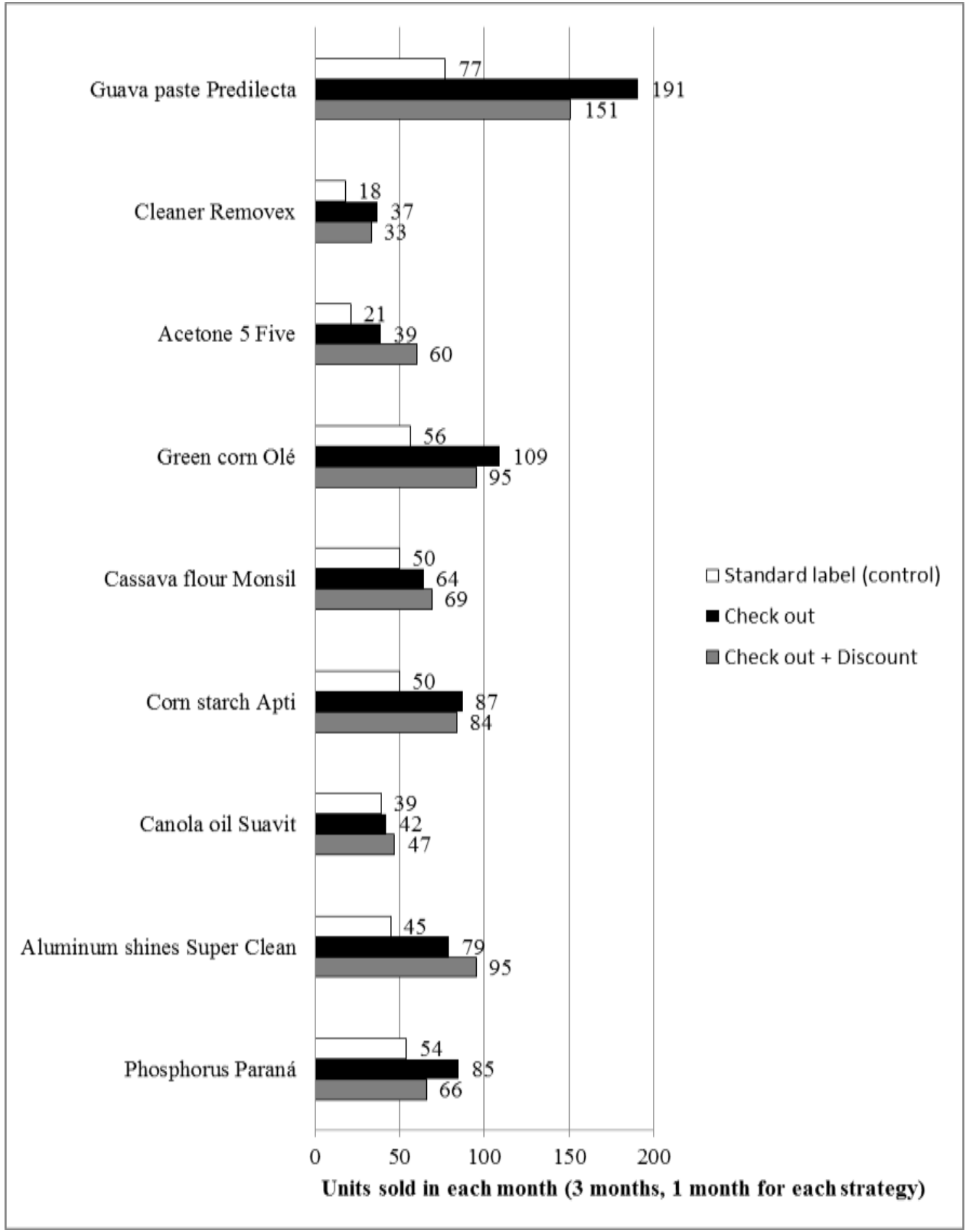

Figure 3 - Total unit sales of each product in June, July and August 2011

\subsection{SUPER CLEAN ALUMINUM POLISH}

Sales of Super Clean aluminum polish increased significantly with the new price presentation strategies. Both the compare appeal and compare: 30\% discount appeal increased sales. According to Figure 3, 45 units were sold with the standard price label, 79 with the compare poster and 95 with addition of the discount appeal. 
Average sales of this product in 2010 had small variations, of $M=1.56, M=1.81$ and $M=1.62$ for June, July and August, respectively. The overall daily means between June 2010 and June 2011 were close $(M=1.56$ versus $M=1.80)$. Thus, once again there is a good chance for future variations from new price presentation forms.

The results for July 2011 showed the influence of the compare poster, which caused a difference of 1.14 in relation to the standard price label: $M_{\text {control }}=1.76 \mathrm{vs.} M_{\text {compare }}=2.90(t$ $=1.79 ; p<0.04$ ). Average sales rose from 1.76 to 2.90 , a significant increase of $64 \%$.

In turn, the compare plus discount appeal achieved an even greater increase, of 1.55, in relation to the standard price label, raising mean sales from 1.75 to 3.30 , or $88 \%: M_{\text {control }}=$ 1,75 vs. $M_{\text {compare: } 30 \% \text { discount }}=3.30(t=2.24 ; p<0.03)$. Therefore, the number of appeal arguments was directly proportional to the sales, i.e., the more appeals, the higher the sales were.

A comparison with the sector was not important in this case, since the only competitor is the Brilhalumínio polish (500 $\mathrm{ml}$ bottle). The sales history of both products showed the competitor always outsold the Super Clean brand, and with the new price presentation forms, the positions inverted.

The mean sales presented by the competitor were $M_{\text {compare }}=3.09$ vs. $M_{\text {compare: }} 30 \%$ discount $=$ $4.00(t=1.28 ; p<0.21)$. Therefore, once again the compare plus discount appeal was more effective. Nevertheless, both managed to achieve significant results: the greater the number of appeals, the higher the sales were, meaning that the number of consumers trying the product increased, possibly raising its future market share.

\subsection{SUAVIT CANOLA OIL}

There were no significant differences that could indicate the efficacy of a particular price presentation strategy for Suavit canola oil. As shown by Figure 6, the total sales of canola oil were 39 units with the standard price label, 42 with the compare poster and 47 with the compare plus discount poster. The greatest variation observed was only $12 \%$. As can be seen in Figure 7, sales were relatively stable in 2010, when the averages were $M=1.36$ in June, $M=1.19$ in July and $M=1.31$ in August.

Those figures changed significantly in 2011. Average sales of the product were $M_{\text {control }}=$ 1.66 vs. $M_{\text {compare }}=1.95(t=0.53 ; p=\mathrm{NS}), M_{\text {control }}=1.80$ vs. $M_{\text {compare: }} 30 \%$ discount $=1.95(t=0.31$; $p=\mathrm{NS})$ and $M_{\text {compare }}=1.76$ vs. $M_{\text {compare: }} 30 \%$ discount $=1.95(t=0.40 ; p=\mathrm{NS})$. The direction of the 
average sales was as expected, suggesting that more promotional appeals tend to increase sales of the product, but the results were not significant.

The canola oil sector of the market consists of three brands: Suavit, Salada and Liza. Average sales of these three brands considered together in 2011 were $M=2.32$ in June, $M=$ 2.81 in July and $M=2.85$ in August. There was a $21 \%$ increase from the first to the second month and a $23 \%$ increase from the first to the third month.

The inefficacy of the new price presentation forms can be explained by the characteristics of the product and its customers. It is a premium product, with a price about $97 \%$ higher than that of soy oil (the most popular variety), and the predominant income level of the customers of the store studied was middle and lower-middle class. These customers are characterized by focus on basic items, so it is likely that new selling appeals had relatively less effect on them with respect to premium products. The conclusion is that neither of the two new presentation forms was effective, because there were no significant variations in sales.

\subsection{APTI CORNSTARCH}

According to Figure 8, the total sales of Apti cornstarch were 50 units in June (standard price label), 87 in July (compare appeal) and 84 in August (compare and discount appeal). There were no surprises in these results. There was an increase with the compare appeal, followed by a small decline with the compare plus discount appeal. The data show the product maintained relatively constant sales in 2010, of $M=1.84$ in June, $M=1.89$ in July and $M=$ 1.65 in August that year, when there was growth of $3 \%$ from the first to the second month and a decline of $13 \%$ from the second to the third.

The sales of the product in 2011 with implementation of the strategies were $M_{\text {control }}=$ 2.19 vs. $M_{\text {compare }}=3.33(t=1.20 ; p=\mathrm{NS}), M_{\text {control }}=2.15$ vs. $M_{\text {compare: } 30 \% \text { discount }}=3.15(t=0.79$; $p=\mathrm{NS})$ and $M_{\text {compare }}=3.76$ vs. $M_{\text {compare: }} 30 \%$ discount $=3.19(t=0.48 ; p=\mathrm{NS})$. There was an increase of about $50 \%$ from the normal price label to the compare appeal.

The supermarket studied carries three brands of cornstarch: Apti, Quero and Maizena (the last the leader in the category, with a market share of nearly 50\% and a history going back 130 years). The average sales of the sector in 2011 were $M=8.00$ in June, $M=9.69$ in July and $M=8.38$ in August, meaning growth of $21 \%$ from June to July and a fall of $14 \%$ from July to August. Therefore, the compare appeal achieved higher growth for the target brand than that of the sector: $67 \%$ against $21 \%$. 
In 2011 the competing brand Quero, with the same package size and similar price (R\$ 2.59), showed sales of $M=2.40$ in June, $M=1.61$ in July and $M=1.80$ in August. The declines recorded in the second and third months can be related to the growth of sales of the Apti brand, which diverted sales from its direct competitor. The compare appeal achieved greater growth than that of the sector, probably because of this product switching.

\subsection{MONSIL CASSAVA FLOUR}

Sales of Monsil cassava flour were little influenced by the new forms of price presentation. As can be seen in Figure 10, 50 units were sold with the standard price label, 64 with the compare poster and 69 with the compare plus discount appeal. These figures represented increases with respect to the first month of $28 \%$ with the compare appeal and $38 \%$ with addition of the discount. According to Figure 11, average sales in 2010 were relatively stable, at $M=1.96$ in June, $M=1.89$ in July and $M=2.08$ in August (the greatest variation was only $10 \%)$.

In 2011 the comparative sales were $M_{\text {control }}=2.09$ vs. $M_{\text {compare }}=2.33(t=0.40 ; p=\mathrm{NS})$, $M_{\text {control }}=2.10$ vs. $M_{\text {compare: }} 30 \%$ discount $=2.35(t=0.37 ; p=\mathrm{NS})$ and $M_{\text {compare }}=2.66$ vs. $M_{\text {compare }} 30 \%$ discount $=2.66(t=0.00 ; p=\mathrm{NS})$. There was an increase of approximately $20 \%$ from the first to the second month and of $8 \%$ from the second to the third. Therefore, the increase was directly proportional to the number of appeals.

The cassava flour sector in the store consists of two brands and two types: Monsil $1 \mathrm{Kg}$ white and toasted and Pinduca $1 \mathrm{Kg}$ white and toasted. The variations in the product analyzed did not follow the pattern for the sector, because the growth was continuous, peaking in the third month. Perhaps the presence of the compare plus discount appeal prevented a dip in the sector. According to the mentioned data, the compare appeal did not attain the growth of the cassava flour sector as a whole, while the compare plus discount appeal performed better, with sales in August 33\% higher than in June, in comparison to the decline in the sector, although the differences were not statistically significant, so no inferences can be drawn about the efficacy of one or the other form of price presentation.

\subsection{OLÉ CORN}

Sales of Ole corn rose with the compare appeal, followed by a small decline with the compare plus discount appeal. According to Figure 12, sales of the product in 2011 were 56 units in June, 109 in July and 95 in August. The most effective sales technique was therefore the compare appeal. 
As shown by Figure 13, the average sales of corn in 2010 were lower than in 2011, by $M=0.40, M=0.78$ and $M=0.50$ in June, July and August. These differences might be due to one of the limitations of this study, the lack of knowledge about out-of-stock items and shelf space in 2010, so the sales in 2010 cannot serve as a parameter.

In 2011, the average sales were $M_{\text {control }}=2.28, M_{\text {compare }}=3.85$ and $M_{\text {compare: } 30 \% \text { discount }}=$ 4.23. This represented growth of $87 \%$ from the first to the second month and a decline of $13 \%$ from the second to the third. The pairwise comparisons were $M_{\text {control }}=2.28$ vs. $M_{\text {compare }}=3.85$ $(t=1.35 ; p=\mathrm{NS}), M_{\text {control }}=2.45$ vs. $M_{\text {compare: }} 30 \%$ discount $=4.20(t=1.49 ; p<0.15)$ and $M_{\text {compare }}=$ 4.95 vs. $M_{\text {compare: }} 30 \%$ discount $=4.23(t=0.45 ; p=\mathrm{NS})$. Therefore, the compare appeal was more effective than the combined appeal.

The canned corn sector in the supermarket showed average sales of $M=36.96, M=$ 45.00 and $M=38.00$ in June, July and August 2011, respectively. Thus, there was an increase of $22 \%$ from June to July and a decrease of $16 \%$ from July to August. The brand studied performed similarly, with increased sales in the second month followed by a decline in the third. However, the compare appeal produced sales growth well above the sector, with an increase of $87 \%$ against only $22 \%$ for the sector.

The data thus show that the compare appeal achieved the best performance by far (an increase nearly four times greater in percentage terms). The addition of the discount appeal maintained sales well above those of June and possibly softened the overall decline of the sector. However, the statistics show that no variation is sufficient to prove the efficacy of the new forms of price presentation.

\subsection{ACETONE SPOT REMOVER}

Sales of the spot remover grew strongly with both price presentation forms: sales practically tripled from the first to the third month. As can be seen in Figure 14, 21 units were sold with the standard price label, 39 with the compare appeal and 60 with the discount appeal added. According to Figure 15, the sales in 2010 also increased during the three months, with $M=0.76, M=1.37$ and $M=2.00$ for June, July and August, respectively, or a $163 \%$ increase from tie first to the third month.

In 2011, the average sales movement was similar to that in 2010, with the following figures: $M_{\text {control }}=0.71$ vs. $M_{\text {compare }}=1.57(t=1.95 ; p<0.06), M_{\text {control }}=0.95$ vs. $M_{\text {compare: } 30 \%}$ discount $=2.30(t=2.67 ; p<0.01)$ and $M_{\text {compare }}=1.57$ vs. $M_{\text {compare: }} 30 \%$ discount $=2.33(t=1.27$; $p=\mathrm{NS})$. There was a significant increase of $121 \%$ from the control to the compare appeal and 
also a substantial increase of $142 \%$ from the control to the compare: $30 \%$ discount appeal, but the difference between the two enhanced price presentations was not significant.

The supermarket studied carries three spot remover brands: 5 Cinco, Risqué and Farmax. In 2011, 5 Cinco presented sales figures of $M=4.84$ in June, $M=6.34$ um July and $M=7.00$ in August. Therefore, sales of the brand studied outpaced the growth of the sector.

Although both strategies produced significant variations, nothing can be concluded for this product, since the variations in sales in the sector in 2011 were very similar to those in 2010.

\subsection{REMOVEX HOUSEHOLD CLEANER}

Sales of Removex cleaner grew strongly with the compare appeal followed by a drop with the compare plus discount appeal. This pattern ran counter to the general growth of the sector. As shown in Figure 16, a total of 18 units were sold in June, 37 in July and 33 in August. The comparative averages for 2011 were $M_{\text {control }}=0.66$ vs. $M_{\text {compare }}=2.47$, a change of $274 \%(t=1.95 ; p<0.02), M_{\text {control }}=0.75$ vs. $M_{\text {compare: }} 30 \%$ discount $=1.25$, a change of $66 \%$ $(t=1.64 ; p<0.11)$, and $M_{\text {compare }}=1.47$ vs. $M_{\text {compare: }} 30 \%$ discount $=1.28$, a variation of $87 \%(t=0.56$; $p=\mathrm{NS})$.

The supermarket carries two brands of household cleaners, in two sizes: Removex 1 liter and 2 liters and Super Clean 1 liter and 2 liters. In 2011, the daily average sales of all products were $M=2.44, M=2.61$ and $M=3.07$ in June, July and August, respectively, growth in all months. Therefore, the compare appeal generated growth of the target product far above that of the sector as a whole - 97\% against $7 \%$ - while the compare plus discount appeal went against the grain, with a drop of $11 \%$ against growth of $18 \%$ for the sector.

An important observation is that the Removex 1 liter size showed average sales of $M=$ 1.16 in June, $M=0.65$ in July and $M=0.96$ in August. Therefore, the increased sales of the Removex 2-liter size might have been related to the lower sales of the smaller bottle. This indicates the efficacy of the compare appeal, because it generated a significant increase in sales, exceeding that of the overall sector more than threefold, but perhaps achieved through higher sales of the larger size (2 1) in detriment to the smaller one (1 1). The addition of the discount appeal did not increase sales significantly, or even keep pace with the growth of the sector.

\subsection{PREDILECTA GUAVA PASTE}

Guava paste was the most surprising case of this study: its sales remained virtually constant in the three months of 2010 and increased dramatically with the addition of greater 
stimuli in 2011. According to Figure 18, total sales of the product rose from 77 in June to 191 in July before dipping to 151 in August, an increase of $148 \%$ with the compare appeal followed by drop of $20 \%$ with addition of the discount appeal. As can be seen in Figure 19, in 2010 the product's average daily sales were $M=3.04$ in June, $M=2.96$ in July and $M=3.27$ in August, with the greatest variation being $10 \%$. Therefore, there is a good chance of future variations from new forms of price presentation.

In 2011, the product obtained comparative sales of $M_{\text {control }}=3.28$ vs. $M_{\text {compare }}=7.28$ $(t=2.45 ; p<0.02), M_{\text {control }}=3.15$ vs. $M_{\text {compare: } 30 \% \text { discount }}=6.15(t=2.62 ; p<0.017)$ and $M_{\text {compare }}=$ 7.71 vs. $M_{\text {compare: }} 30 \%$ discount $=5.61(t=1.24 ; p=\mathrm{NS})$. Note the significant increases of $121 \%$ from the standard price label to the compare appeal and of $100 \%$ from the standard price label to the compare plus discount appeal. Hence, the compare appeal was a more effective selling strategy than the combined appeals.

Comparison with the entire sector was not relevant for this product, since sales of competing brands were negligible, so the data for the sector are basically dictated by the Predilecta brand. According to the figures mentioned above, both new strategies were effective, although the use of the poster with "compare" alone was most effective. In this case, the greater stimulus of the poster might have attracted the attention of shoppers to the lower part of the shelf (where the product is located). The good performance of the new price presentations can perhaps be explained by the fact this product is not a staple item, so it is more often purchased on impulse.

\subsection{ANALYSIS OF THE IMPACT OF MARKETING STRATEGIES ON REVENUE}

We also analyzed the sales series for the nine products multiplied by the number of business days in each of the three months. This market does not stay open seven days a week, so it was open only 25 days in June, 26 in July and 26 in August. The data on number of items sold per product was regressed against the gross revenue in each month (June to August), with the focus of identifying which of the nine products (if not all nine) impacted the store's sales revenue (dependent variable). The gross monthly revenue figures for the supermarket in 2011 were $\mathrm{R} \$ 925,152.93$ in June; $\mathrm{R}$ \$ 1,054,511.47 in July and $\mathrm{R} \$$ 995,550.05 in August, while the corresponding daily averages were $\mathrm{R} \$ 37,006.12$ in June, 40,558.13 in July and $\mathrm{R} \$ 38,290.39$ in August.

In a first analysis, the differences between the mean daily revenues were not significant, although they were in the expected direction. When compared with the normal price label, the compare appeal increased revenue $\left(M_{\text {June }}=\mathrm{R} \$ 37,124.02\right.$ vs. $M_{\text {July }}=\mathrm{R} \$ 40,525.83 ; t=0.40$; 
$p=\mathrm{NS}$ ), while the compare plus discount appeal did not cause a significant increase compared to the control $\left(M_{\text {June }}=\mathrm{R} \$ 39,093.00\right.$ vs. $\left.M_{\text {August }}=\mathrm{R} \$ 38,804.32 ; t=0.03 ; p=\mathrm{NS}\right)$ and the compare appeal was better than the compare plus discount $\left(M_{\mathrm{July}}=\mathrm{R} \$ 43,667.70\right.$ vs. $M_{\text {August }}=$ $\mathrm{R} \$ 39,785.05 ; t=0.50 ; p=\mathrm{NS})$.

In June (control), of the nine items that affected the store's sales, only three $(33 \%)$ of them had a significant effect: $\operatorname{corn}(\beta=0.226 ; p<0.007)$, cornstarch $(\beta=0.356 ; p<0.000)$ and matches $(\beta=0.58 ; p<0.000)$. Of them, matches had the greatest weight.

In July, again only three products (33\%) had a significant impact on revenue: guava paste $(\beta=0.649 ; p<0.000)$, spot remover $(\beta=0.378 ; p<0.000)$ and cassava flour $(\beta=0.215$; $p<0.002$ ), with guava paste having the greatest magnitude.

Five products had a significant influence on revenue in August, generating a variation of $56 \%$ : spot remover $(\beta=0.321 ; p<0.005)$, corn $(\beta=0.447 ; p<0.000)$, cornstarch $(\beta=0.248$; $p<0.007)$, cassava flour $(\beta=0.0182 ; p<0.000)$ and aluminum polish $(\beta=0.20 ; p<0.033)$. Of the five, spot remover $(\beta=0.321)$ and corn $(\beta=0.447)$ had the greatest weight.

Therefore, 5 Cinco spot remover, Olé corn, Apti cornstarch and Monsil cassava flour merit greater attention from store managers for new actions or studies, since they were the only ones that impacted sales in two of the three of the months analyzed.

Table 3 - Stepwise Regression Analysis of the Effects of the Products on Store Revenue (Using the Control, Compare and Compare Plus Discount Strategies)

\begin{tabular}{|c|c|c|c|c|}
\hline Independent Variables & $\begin{array}{c}\text { Standardized } \\
\text { Beta }\end{array}$ & $t$-value & $p$-value & $\mathbf{R}^{2}$ \\
\hline Matches & 0.58 & 6.51 & 0.000 & \\
\hline Cornstarch & 0.35 & 4.46 & 0.000 & \\
\hline Corn & 0.22 & 2.98 & 0.007 & \\
\hline Dependent Variable: Revenue in June 2011 (control) & & & & $92 \%$ \\
\hline Guava paste & 0.64 & 10.84 & 0.000 & \\
\hline Spot remover & 0.37 & 6.52 & 0.000 & \\
\hline Cassava flour & 0.12 & 3.53 & 0.002 & \\
\hline Dependent Variable: Revenue in July 2011 (compare) & & & & $89 \%$ \\
\hline Spot remover & 0.32 & 3.15 & 0.005 & \\
\hline Corn & 0.44 & 5.27 & 0.000 & \\
\hline Cornstarch & 0.24 & 2.98 & 0.007 & \\
\hline Cassava flour & 0.18 & 4.46 & 0.000 & \\
\hline Aluminum polish & 0.20 & 2.28 & 0.03 & \\
\hline $\begin{array}{l}\text { Dependent Variable: Revenue in August } 2011 \text { (compare: } 30 \% \\
\text { discount) }\end{array}$ & & & & $86 \%$ \\
\hline
\end{tabular}




\subsection{ANALYSIS OF THE SHELF POSITION}

The nine products studied were evenly divided in their shelf position: Paraná matches, Super Clean aluminum polish and Suavit canola oil on the upper shelves; Apti cornstarch, Monsil cassava flour and Olé corn in the middle part (prime space); and 5 Cinco spot remover, Removex household cleaner and Predilecta guava paste on the lower part. We created a new variable, representing the shelf position of each item, to test the variance of the series. Therefore, the variable middle position reflects the average of the three variables for Apti cornstarch, Monsil cassava flour and Olé corn. The three new variables were middle, lower and upper.

Direct effects. In June, when the stimulus was only the normal price label, the position that stood out in sales was the prime position, with an average of 2.31, followed by the upper position with 2.04 and the lower one with $1.64\left(F(2,48)=0.66 ; p<0.51 ; \eta^{2}=3 \%\right)$. In July, with use of the compare poster, there was an interesting inversion: the lower position (the smallest seller previously) became the biggest seller, reaching 3.66 (increase of $121 \%$ ), followed by the prime position with 3.52 (growth of $60 \%)$ and the upper one with $3.18(F(2,48)=0.14$; $\left.p<0.87 ; \eta^{2}=1 \%\right)$. In the last month of the study, with the addition of the discount appeal, the prime position returned to first place, with 3.16 (decline of $4.5 \%$ ), followed by the lower position with 3.53 (fall of $8.5 \%)$ and the upper position with $2.79\left(F(2,48)=2.24 ; p<0.47 ; \eta^{2}=\right.$ $1 \%)$. Based on these data, the initial assumption that the prime area is most propitious for sales was confirmed, since it attained the highest sales of the products studied in two of the three months (June and August). The lower position was in second place and was greatly enhanced by the added stimuli (an increase of $121 \%$ with the compare poster). Finally, the upper position was the worst display area, since only in June (when there was no special stimulus) did it not occupy the last position - in July and August it was the worst selling position.

The shelf position did not have a direct effect on average sales $(F(2,226)=1.24 ; p<0.29$; $\eta^{2}=1 \%$ ), but the promotional appeal in the form of price presentation did have a direct effect $\left(F(2,226)=10.34 ; p<0.00 ; \eta^{2}=8 \%\right)$. With respect to communication, there was a significant difference between the control presentation and the compare appeal of $\Delta=1.31(p<0.000)$ and between the control and compare plus discount, of $\Delta=1.16(p<0.0001)$. There was no significant difference between the compare and compare plus discount strategy, $\Delta=0.14$ $(p=\mathrm{NS})$. The correlation matrix presented in Table 4 shows the associations. 


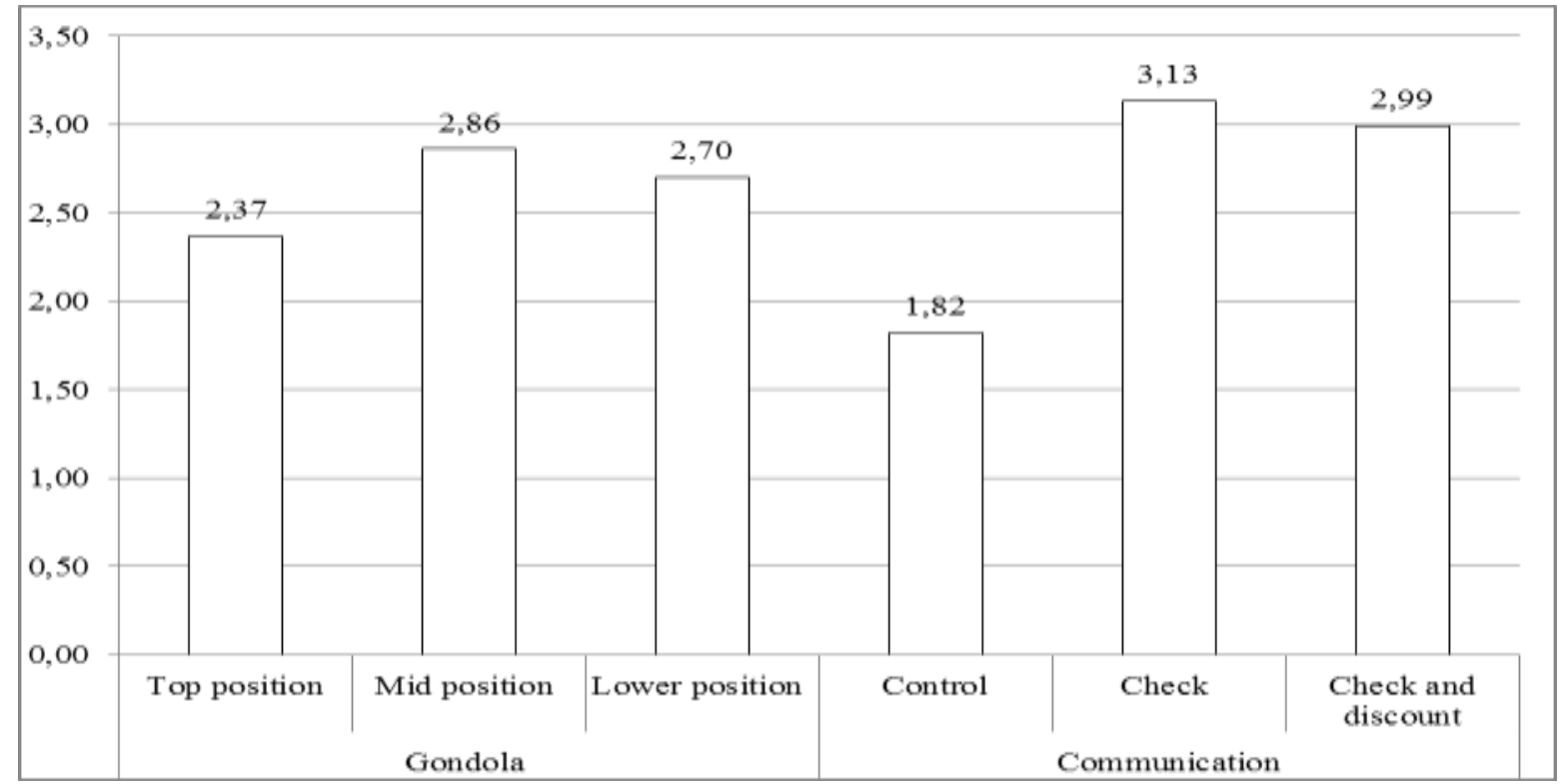

Figure 4 - Average sales (in units) of the positions and price presentations

Interactive effects. Finally, we tested the interaction of the form of price presentation $\mathrm{x}$ shelf position on the average product sales. The interaction was significant $(F(2,48)=3.13$; $\left.p<0.002 ; \eta^{2}=10 \%\right)$. With the traditional price presentation or the compare plus discount appeal, the prime shelf position was the most efficient. However, when the appeal was only the compare poster, the lower position was the most efficient seller.

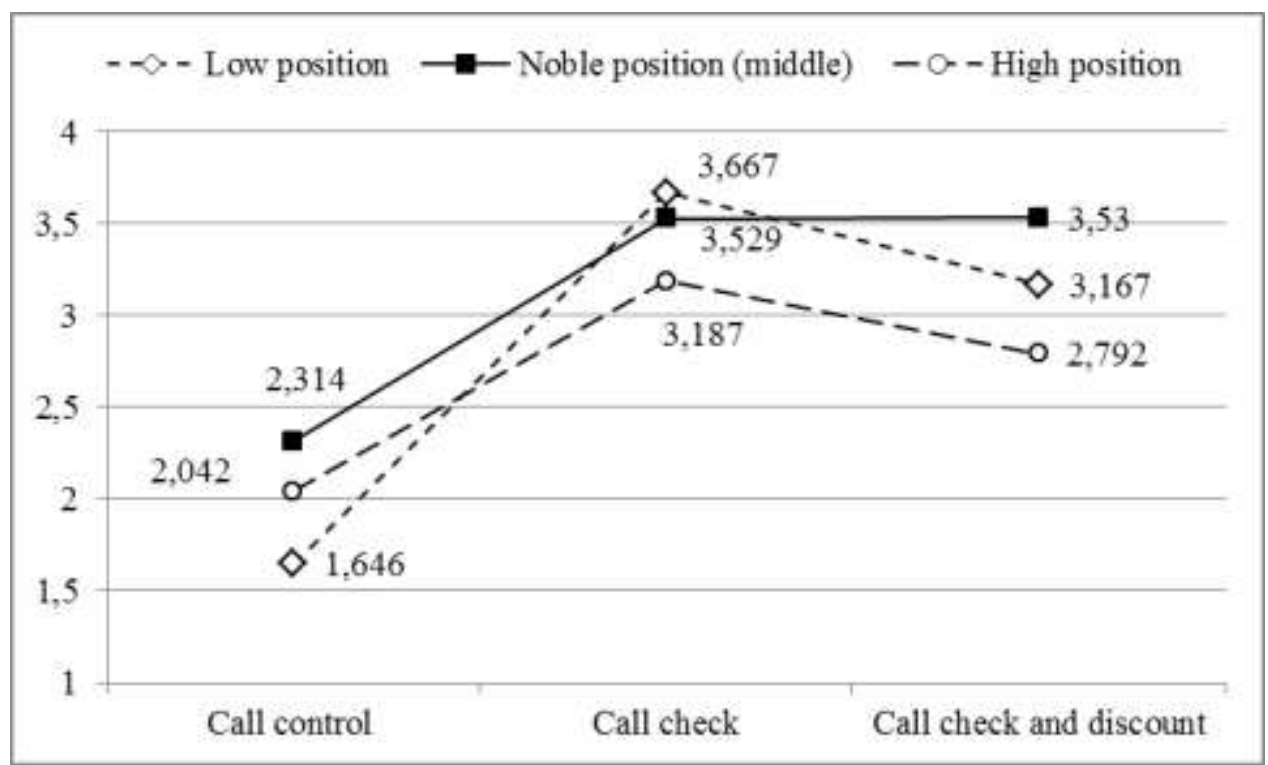

Figure 5 - Interaction on average sales (in units) of the positions and price presentations

\section{FINAL CONSIDERATIONS}

The aim of this study was to investigate the influence of forms of price presentation and shelf position on supermarket sales. We used the standard price label for the base month and in the following months introduced two new forms, one a poster urging shoppers to "compare" and the other a similar poster adding the appeal " $30 \%$ discount". We then analyzed 
the performance of the price presentation on nine products (three from each shelf position), including investigating which ones had the greatest impact on the store's revenue and the performance of each shelf position.

The first analysis confirmed that greater stimuli promote higher sales, since the sales of all the products analyzed, taken together, increased over the base month with the new forms of price presentation. It also showed that five of these variations were significant, involving three products (33\%): Super Clean aluminum polish, Removex household cleaner and Predilecta guava paste. But only the aluminum polish presented peak sales with the addition of the discount appeal (30\% off). The two others sold best with just the compare appeal (counter to the assumption that more appeals would translate into higher sales).

The second analysis showed that of the nine items studied, those that deserve the most attention from store managers for new marketing actions or research are 5 Cinco spot remover, Olé corn, Apti cornstarch and Monsil cassava flour, for being those with the greatest significant impact on the store's revenue (in two of the three months analyzed).

Finally, the last analysis confirmed the initial assumption that the middle (prime) shelf area is most propitious for sales (it obtained the best sales in two of the three months). The lower position was in second place and was greatly enhanced by the stronger stimuli (an increase of $121 \%$ from the standard price label to the compare appeal). The upper position was the worst (lowest sales in two of the three months analyzed).

Limitations and suggestions for future research: the first limitation is that the study covered very few products. New products should be inserted in future studies, as well as a wider variety, including staples like rice and cornmeal and prepared foods like crackers, among others. The second limitation was the period of study. Four or five months instead of three could generate more relevant information and add insight into consumers' buying behavior. Another timing consideration for future studies would be to use weeks, controlling for the period of receipt/payment. Keeping the same price for three or four months can be difficult in a country with high inflation. Third, the type of promotion employed in the store is a limitation that needs to be addressed. Future studies could use other discount percentages or types of promotion. Finally, choosing products that take up similar shelf space could generate more significant findings, because in this study, the space occupied by cornstarch is obviously much greater than that taken up by canned corn. 


\section{REFERENCES}

ALVAREZ, B.; CASIELLES, R. V. Consumer evaluations of sales promotion: the effect on brand choice. European Journal of Marketing, v. 39, n. 1, p. 54-70, 2005.

ALVES, A. P. Organização da gôndola aumenta a lucratividade. São Paulo, 2008.

Disponível em: <http://www.vendamuitomais.com.br/site/artigo.asp?Id=119

Categoria=Lucro>. Acesso em: 30 jun. 2011.

BAGCHI, R.; DAVIS, D. F. \$29 for 70 items or 70 items for \$29? How presentation order affects package perceptions. Journal of Consumer Research, v. 39, n. 3, p. 421-435, 2002.

BAKER, M.J., CHURCHILL, G.A. The impact of physically attractive models on advertising evaluations. Journal of Marketing Research, v. 14, n. 3, p. 538-555, 1977.

BARNES, J. G. Factors influencing consumer reaction to retail newspaper 'sale' advertising. Proceedings of the American Marketing Association, p. 471-477, 1974.

BAWA, K.; SHOEMAKER, R. W. The effects of a direct mail coupon on brand choice behavior. Journal of Marketing Research, v. 24 n. 4, p. 370-376, 1987.

BELCH, G. E. An examination of comparative and non-comparative television commercials: the effects of claim variation and repetition on cognitive response and message acceptance, Journal of Marketing Research, v. 18, n. 4, p. 333-349, 1981.

BERKOWITZ, E. N.; WALTON, J. R. Contextual influences on consumer price responses: an experimental analysis. Journal of Marketing Research, v. 17, n. 3, p. 349-358, 1980.

BLACKWELL, R. D.; MINIARD, P. W.; ENGEL, J. F. Consumer behavior. 8. ed. Orlando: The Dryden Press, 2008.

CESARINO, R. C.; CAIXETA FILHO, J. V. Alocação dos produtos nas gôndola dos supermercados: estudo de caso. Gestão e Produção, v. 9, n. 1, p. 45-61, 2002.

CHANDON, P.; WANSINK, B.; LAURENT, G. A benefit congruency framework of sales promotion effectiveness. Journal of Marketing, v. 64, n. 2, p. 65-81, 2000.

CHANDRASHEKARAN, R.; GREWAL, D. Assimilation of advertised reference prices: the moderating role of involvement. Journal of Retailing, v. 79, n. 1, p. 53-62, 2003.

CHANDRASHEKARAN, R.; COMPEAU, L. D. E.; GREWAL, D. Comparative price advertising: believe it or not. Journal of Consumer Affairs, v. 36, n. 2, p. 284-294, 2002.

COMANOR, W. S.; WILSON, T. A. The effect of advertising on competition. Journal of Econometric Research, v. 18, n. 2, p. 453-76, 1974.

DAVIS, S.; INMAN, J.; MCALISTER, J. Promotion has a negative effect on brand evaluations - or does it? Additional disconfirming evidence. Journal of Marketing Research, v. 29, n. 1, p. 143-118, 1992.

DODSON, J. A.; TYBOUT, A. M.; STERNTHAL, B. Impact of deals and deal retraction on brand switching. Journal of Marketing Research, v. 15, n. 2, p. 72-81, 1978. 
DROGE, C.; DARMON, R.Y. Associative positioning strategies through comparative advertising: attribute versus overall similarity approaches. Journal of Marketing Research, v. 24, n. 4, p. 377-388, 1987.

EHRENBERG, A. S. C.; HAMMOND, K.; GOODHARDT, G. J. The after effects of pricerelated consumer promotions. Journal of Advertising Research, v. 34, n. 2, p. 11-21, 1994.

GARRETSON, J. A.; CLOW, K. E. The influence of coupon face value on service quality expectations, risk perceptions and purchase intentions in the dental industry. Journal of Services Marketing, v. 13, n. 1, p. 59-68, 1999.

GOLDEN, L.L. Consumer reactions to explicit brand comparisons in advertisements. Journal of Marketing Research, v. 16, n. 4, p. 517-532, 1979.

GOODWIN, S. A.; ETGAR, H. An experimental investigation of comparative advertising: impact of message appeal, information load, and utility of product class. Journal of Marketing Research, v. 17, n. 2, p. 187-202, 1980.

GREWAL, D. et al. Comparative versus non-comparative advertising: a meta-analysis. Journal of Marketing, v. 61, n. 1, p. 1-16, 1997.

GUEGUEN, N.; JACOB, C. Nine ending price and consumer behavior: an evaluation in a new context. Journal of Applied Sciences, v. 5, n. 2, p. 345-349, 2005

GUPTA, S. Impact of sales promotions on when, what, and how much to buy. Journal of Marketing Research, v. 25, n. 4, p. 342-355, 1988.

HASSELDINE, J.; HITE, P. A. Framing, gender and tax compliance. Journal of Economic Psychology, v. 24, n. 4, p. 517-533, 2006.

HAWKINS, D. I.; MOTHERSBAUGH, D. L.; BEST, R. J. Consumer behavior. 11. ed. New York: Irwin/McGraw-Hill, 2010.

HOGAN, J. Building a world class pricing capability: where does your company stack up? Published by Monitor group. Working Paper. Monitor Group. 2008. Disponível em: <www.monitor.com/.../Monitor_Bldg_WorldClass_Pricing_Capability.pdf>. Acesso em: 21 jun. 2011.

JACOBY, J.; OLSON, J. Consumer responses to price: an attitudinal information processing perspective. WIND, Y.; GREENBERG, M. Moving ahead with attitude research. (eds.). Chicago: American Marketing Association, 1977. p. 73-86.

JONES, S. C.; LYNCH, M. A pilot study investigating of the nature of point of sale alcohol promotions in bottle shop in a large Australian regional city. Australian and New Zeeland Journal of Public Health, v. 31, n. 4, p. 318-321, 2007.

KAMEN, J. M.; TOMAN, R. J. Psychophysics of prices. Journal of Marketing Research, v. 1, n. 1, p. 27-35, 1970.

LAROCHE, M. et al. Consumers use of price promotions: a model and its potential moderators. Journal of Retailing and Consumer Services, v. 8, n. 2, p. 251-260, 2001. 
LEE, C. W. Sales promotions as strategic communication: the case of Singapore. Journal of Product and Brand Managment, v. 11, n. 2/3, p. 103-114, 2002.

LIAO, S. L. The effects of nonmonetary sales promotions on consumer preferences: the contingent role of product category. Journal of American Academy of Business, v. 8, n. 2, p. 196-203, 2006.

MELA, G. F.; GUPTA, S.; LEHMANN, D. R. The long term impact of promotion and advertising on consumer brand choice. Journal of Marketing Research, v. 34, n. 2, p. 248$261,1997$.

MITRA, A.; LYNCH JUNIOR, J. G. Toward a reconciliation of market power and information theories of advertising effects on price elasticity. Journal of Consumer Research, v. 21, n. 3, p. 644-659, 1995.

MONROE, K. B. Pricing: making profitable decisions. 2. ed. New York: McGraw-Hill, 1990.

NAGLE, T. T.; HOGAN, J. E.; ZALE, J. The strategy and tactics of pricing. 5. ed. Prentice Hall: New Jersey, 2011.

NELSON, P. Advertising as information. Journal of Political Economy, v. 78, p. 311-329, mar./abr. 1974.

NEVIN, J. R. Laboratory experiments for estimating consumer demand: a validation study. Journal of Marketing Research, v. 11, n. 3, p. 261-268, 1974.

NIELSEN. A. C. Pesquisa demonstra que consumo brasileiro é pulverizado entre grandes cadeias e demais supermercados. São Paulo, 2011. Disponível em:

<http://br.nielsen.com/news/Shopper_pulverizado.shtml>. Acesso em: 15 jun. 2011.

PAPATLA, P.; KRISHNAMURTHI, L. Measuring the dynamic effects of promotions on brand choice. Journal of Marketing Research, v. 33, n. 1, p. 20-35, 1996.

PEATTIE, K.; PEATTIE, S. Sales promotion: a missed opportunity to service makerters. International Journal of Service Industry Management, v. 6, n. 1, p. 22-39, 1995.

PECHMANN, C.; RATNESHWAR, S. The use of comparative advertising for brand positioning: association versus differentiation. Journal of Consumer Research, v. 18, n. 3 , p. 145-160, 1991.

PECHMANN, C.; STEWART, D. W. How direct comparative ads promoting low, moderate and high share brands affect brand choice. Journal of Advertising Research, v. 31, n. 2, p. 47-55, 1991.

POPAI. Point-Of-Purchase Advertising Institute. Brasil. The global association for marketing at retail: pesquisa sobre o estudo do comportamento do consumidor no ponto-devenda. São Paulo: POPAI Brasil, 2003.

PRADO, G. A.; PRADO, K. P. Um modelo de retorno sobre investimento em ações promocionais não monetarias. Revista Portuguesa e Brasileira de Gestão, v. 8, n. 4, p. 345356, 2003. 
SCHINDLER, R. M.; KIBARIAN, T. M. Increased consumer sales response through use of 99 ending prices. Journal of Retailing, v. 72, n. 2, p. 567-576, 1996.

SRIVASTAVA, J.; CHAKRAVARTI, D. Price presentation effects in purchases involving trade-ins. Journal of Marketing Research, v. 48, n. 5, p. 910-919, 2011.

VILLAREJO-RAMOS, A. F.; SANCHEZ-FRANCO, M. J. The impact of marketing communication and price promotion on brand equity. Journal of Brand Management, v. 12, n. 6, p. 431-444, 2005.

WAKEFIELD, K. L.; BUSH, V. D. Promotion leisure services: economic and emotional aspects of consumer response. Journal of Services Marketing, v. 12, n. 3, p. 209-213, 1998.

\footnotetext{
${ }^{\mathrm{i}}$ http://www.portalnovarejo.com.br/distribuic-o/arquivo/varejo-em-foco/pesquisas-e-fluxo-do-varejo/varejouma-midia-de-massa.
} 